\title{
Integrative review of violence against LGBTQI population in Brazil
}

\begin{abstract}
Regardless of recent achievements of LGBTQI agenda such as recognition of samesex marriage, Brazil is still pointed out as the world leading country in violence against LGBTQI population. In this perspective, an integrative review was performed in the databases EBSCO, Mendley, PubMed, and Scielo using the keywords 'LGBT', 'violence', 'homophobia', 'transphobia'. The search returned 112 articles of which 19 articles were included in this study after applying the excluding criteria. Articles included in the category Review of Education revealed that homophobia impacts negatively on school commitment many times leading LGBTQI students to quit school. Supportive teachers can have a positive effect to students who experience homophobic violence, therefore, gender and sexual diversity need to be included into bachelors of education or teaching training. The category legislation and policies pointed out that the judiciary power is responsible for some of the current achievements, the executive power has addressed some policies but these policies have been facing many barriers, and the legislative power is acting as one of these barriers mainly because of its religious front. The category Review of Sexuality Issues revealed that the transvestite population faces physical e verbal aggression constantly, and have poor networks of support, a situation that enhances vulnerability to HIV/AIDS. The articles of this category also pointed the need of more studies measuring intra-familiar homophobia, and intimate partner violence. The studies have also shown that Catholics, historical Protestants and Pentecostals a more likely to disapprove homosexuality when compared to religious nones and followers of Spiritist traditions, and LGBTQI people linked to African-Brazilian religions are more vulnerable to violence due to their faith and sexual orientation. Studies taking account of social markers, quantifying the violence, and measuring effectiveness of policies are some of the gaps that need to be addressed in future research.
\end{abstract}

Volume 5 Issue 2 - 2018

\author{
Wendy Delgado da Cunha,' Leonora \\ Rezende Pacheco ${ }^{2}$ \\ 'Nursing Undergraduate student, Universidade Federal do \\ Tocantins, Brazil \\ ${ }^{2}$ Nursing Department of Nursing, Universidade Federal do \\ Tocantins, Brazil
}

Correspondence: Leonora Rezende Pacheco, Professor at Nursing Department, Universidade Federal do Tocantins, Brazil, Tel +55 (63) 3232-8334/8400-9466,

Email lerezende@hotmail.com

Received: February 22, 2017 | Published: April II, 2018

Keywords: LGBTQI, violence, homophobia, brazil

\section{Introduction}

An article published in the Journal Liminalis pointed out that 'Brazil is the world champion in homophobic crimes: 190 murders in 2008, followed by Mexico with 35 and the U.S.A. with 25'.1 In her report, Balzer portrays a scary reality of violence against lesbian, gay, bisexual, transvestite, transsexual, queer, and intersexual people (LGBTQI) around the world. Balzer used as reference an organization called Grupo Gay da Bahia (GGB) which has been compiling the numbers of this violence in Brazil since 1980. According to GGB, the reported murders of LGBTQI people in Brazil have increased 55\% in 2008 compared to the years before, also according to this organization the major motivations to this violence are: [...] racism, machismo, religious intolerance, homophobia and ethnocentrism, leading its actors generally to practice a high level of physical violence and moralistic contempt towards the victim, because the murders are often preceded by torture, the use of multiple weapons and a large number of blows (GGB, as quoted in Balzer, 2009).1

In addition, GGB assumed that its report does not depict the reality since it is based on newspapers and internet articles because of the lack of Governmental statistics. Even though the law $n^{\circ} 10.778$ (Brasil, 2003) determines the compulsory notification of violence against vulnerable populations such as LGBTQI population, by health professionals in public and private services, there are no official statistics, therefore, the numbers of violence against this population in Brazil may be much higher than the ones portrayed by GGB. Several researchers state that the field of research related to LGBTQI issues in Brazil is beginning and much more research is needed. ${ }^{2,3}$

Firstly, it is important to understand some concepts such as homophobia, transphobia, and violence. On one hand, there is a discussion in the academic field around the meaning and the use of the term homophobia since it is, somehow, approximated to a phobia because of irrationality, fear, and anxiety. On the other hand, Madureira argued that homophobia is not a simple phobia, it is a result of a collective historical-cultural construction. ${ }^{3}$ In the same way, researchers discuss the use of the term transphobia because homophobia can exclude the trans genders (i.e. gender identity or expression that deviates from the cultural norm of birth sex) in its meaning.

Moreover, this study does not aim to discuss these concepts; they will be used to refer the prejudice against LGBTQI people. In addition, the concept of violence considered here is any type of physical, psychological, or patrimonial injury, including explicit forms of violence (i.e. clearly known) or implicit forms (i.e. hidden by routines, social patterns, etc.).

Since Brazil is pointed as the leading country in violence against LGBTQI people and there is a lack of official statics, this study aims to review the scientific literature of the last 5 years regarding violence against Brazilian LGBTQI population. This study looks at the Brazilian aspects and places linked to the development of the 
prejudice against LGBTQI people, violence reports, and research gaps. Several researchers have been interested in the Brazilian aspects that lead to this prejudice, findings demonstrate a direct relation among homophobia or transphobia and the historical-cultural aspects of Brazilian society, education, and religion..$^{2-6}$ Since Brazil remains as an unsafe place for LGBTQI population, studies investigating the triggers of this violence, violence reports, and studies measuring effectiveness of public programs to combat homophobia are extremely necessary to guide future actions to protect this vulnerable population.

\section{Methods}

An integrative review is a research method in which the analyses of relevant studies give guidance to decision-making and improvement of clinical practice. This kind of research synthesizes the knowledge of a specific subject and points out the knowledge gaps that need to be addressed in future studies. ${ }^{7}$ The presented study was built according to the following steps: identification of theme and construction of the guiding review question, establishment of including and excluding criteria, literature search, categorization of included articles, analysis and discussion of results, and, finally, synthesis of knowledge. According to the resolution $n^{\circ} 466 / 2012$ (CEPE, Brasil) the current study does not need approval of the local ethical committee since it does not involve human beings.

Since Brazil is pointed as a leading country in statistics of violence against LGBTQI population, and there is a lack of governmental statistics our study aims to answer: What is the scientific production published in the last five years regarding the theme of violence against LGTQI population in Brazil, and what are the research gaps that need to be addressed?
A review was performed in the databases EBSCO, Mendley, PubMed, and Scielo (Scientific Electronic Library Online) using the keywords 'LGBT', 'Violence', 'Homophobia', 'Transphobia', and 'Brazil' using the connectors 'and' and 'in' which resulted in the following combinations: 'LGBT violence in/and Brazil'; 'LBGT in/and Brazil'; 'Homophobia in/and Brazil', 'Transphobia in/and Brazil'. The search was performed between June 3 and June 10 of 2015 resulting in 112 articles published in English or Portuguese, 60 (53.57\%) articles from Mendley, 24 (21.43\%) from Scielo, 11 (9.82\%) from PubMed, and 17 (15.18\%) from EBSCO. Articles published before 2010, studies not developed in Brazil or not related to the theme, and repeated articles were excluded (93 articles). Nineteen articles, 3 (15.79\%) from Mendley, 3 (15.79\%) from PubMed, 5 (26.32\%) from EBSCO, and 8 (42.1\%) from Scielo were considered relevant to this study and are presented in three different tables according to theme. Seven $(36.84 \%)$ of the selected articles are quantitative studies and the other $12(63.16 \%)$ articles are literature review or qualitative studies. The 19 articles went through a primary analysis and were separated according to theme: $6(31.58 \%)$ articles were included in the category Review of Education (Table 1); the category Review of Legislation and Policies (Table 2) included 6 (31.58\%) articles; in addition, the other $7(36.84 \%)$ articles approached a broad variety of themes such as religion, intimate partner violence, intra-familiar violence, and, therefore, were included in the category Review of sexuality issues (Table 3). A second analysis was performed where the data from the included articles was collect using an instrument to simplify, summarize and organize the findings. Information such as the problem, method, characteristics of the sample, and results was summarized through this instrument and was used in the analysis of each category resulting in the following discussion.

Table I Review of Education

\begin{tabular}{lllll}
\hline Article title & Authors & Method $\quad$ Jearngs
\end{tabular}

Effects of

Homophobic versus

Nonhomophobic

Victimization on

School Commitment

and the Moderating

Effect of Teacher

Attitudes in Brazilian

Public Schools
M. M.Alexander et al. victimization were negatively related to school commitment but homophobic victimization was a stronger predictor. Results supported the hypothesis that supportive teachers can moderate the relationship between victimization and school commitment
Survey Analysis 201I Journal of
LGBTYouth EBSCO

\author{
Theoretical \\ Approaches and \\ Policies in Sexual \\ Diversity and \\ Educational in Brazil:A \\ Critical Review
}

'Diversidade Sexual na Educação' is an important publication as it addresses dynamics of homophobia, heterosexism, and heteronormativity. It could have included more descriptions of effective actions in school, and it could have been written in a more accessible language.

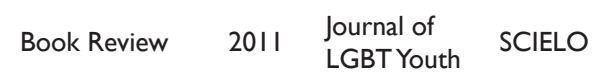


Table Contiuned

\section{Article title}

Authors

Findings

Method

Year Journal

Data basis education: challenges for teacher training
Sexual diversity and

Sexuality is approached in a biological view at School, and bachelors of education do not address sexual diversity, therefore, this theme need to be explored in teaching training and through other strategies.

Students who did not report having been targets of homophobic discrimination evaluate their school experience more positively than their peers who have experienced this kind of discrimination.

Cunha, Josafá

Moreira Da

High School gradur

in Brazil from 2004

to 2008

Elementary and High

School teachers'

perception on

homophobia at school

in Santa Maria (Rio

Grande do Sul / Brazil)

\section{Borges ZN, GR}

Passamani, MI

Ohlweiler, and $M$

Bulsing
Teachers interviewed reported great difficulty in dealing with the issue of homophobia in the classroom. The data principals and mentors is necessary.

Homophobia

And Sexuality In

Adolescents: Sexual

Teixeira FS, Marretto

Trajectories, Risks And

CAR, Mendes AB

Vulnerabilities

Santos EN
There could be many factors affecting the decisions of non-heterosexual youth regarding "coming out of the closet" beyond homophobia such as personal events, life stories and even the revelation of their

$\begin{array}{lll}\text { Literature } & & \begin{array}{l}\text { Sexualidad, } \\ \text { Salud y } \\ \text { Review }\end{array} \text { Sociedad }\end{array}$

Data

Analysis of

socioeconomic questionnaire of the National Examination of High School in Brazil indicated that educational work with school

Semi-

structured

2011 Educar em

SCIELO

Interviews

Revista

Cross-

sectional Study

Psicologia:

2012 Ciência e

Profissão

Table 2 Review of Legislation and Policies

\begin{tabular}{|c|c|c|c|c|c|c|}
\hline Article title & Authors & Findings & Method & Year & Journal & Data basis \\
\hline $\begin{array}{l}\text { Public Measures for } \\
\text { the LGBT Population } \\
\text { in Brazil: Notes } \\
\text { About Reaches and } \\
\text { Possibilities }\end{array}$ & $\begin{array}{l}\text { Mello L, Brito W, } \\
\text { Maroja D }\end{array}$ & $\begin{array}{l}\text { The findings revealed a paradox where there } \\
\text { are some advances in public policies from the } \\
\text { executive power, but these advances still have } \\
\text { minor impact on LGBTQI issues. }\end{array}$ & $\begin{array}{l}\text { Interviews } \\
\text { and } \\
\text { Literature } \\
\text { Review }\end{array}$ & 2012 & $\begin{array}{l}\text { Cadernos } \\
\text { Pagu }\end{array}$ & Mendley \\
\hline
\end{tabular}

The study points to the complexity of the situation of LGBTQI rights in Brazil where advances and contradictions occur transformation of sexual morals in Brazil that

$\begin{array}{lll}\text { Literature } & 2012 & \begin{array}{l}\text { Cadernos de } \\ \text { Saúde Pública }\end{array}\end{array}$

policies, and sexual rights in Brazil simultaneously, revealing a process of still face resistance from political positions.

Carrara, Sergio 
Table Contiuned

$\begin{array}{lllll}\text { Article title } & \text { Authors } & \text { Findings } & \text { Method } & \text { Year Journal Data basis }\end{array}$

Families, Gender Relations and Social Change in Brazil: Practices, Discourse, Policy

Adelman M,

Corrêa de

Azeved M

Brazil, India, South Africa:Transformative Constitutions And Their Role In LGBT Struggles

Hate Behind

Bars: from the construction of sexual orientation as basis for discrimination to the homophobia

Where are the Public Politics for the Brazilian LGBT Population

Freire, L. \& criminalization of
The study reveals a society characterized by tensions between mechanisms sustaining restrictive definitions of family, linked to male dominance, heterosexism and hierarchical gender roles, and those that push toward more egalitarian, diverse and democratic family relations.

This paper argues that a successful LGBTQI articulation in each of these countries draws upon histories of resistance, be they against colonialism in India, racism and military rule in Brazil or apartheid in South Africa.

Literature

Review

2014

International

Journal On

Human Rights

EBSCO

The current strategies to fight homophobia are failing since there is an increase of reports of homophobic violence, highlighting the necessity of the criminalization of homophobic prejudice

Literature what would allow action in national level.

Review

$2012 \quad \begin{aligned} & \text { Sexualidad, } \\ & \text { Sociedad (Rio } \\ & \text { de Janeiro) }\end{aligned}$

SCIELO
EBSCO
Mello L,Avelar R,
Maroja D
This study points out the need for legislative and judicial actions to support the existing programs addressing LGBTQI rights. These programs still face political pressure from conservative and religious fronts of the congress and the senate.
Literature

Review and

Interviews

2012 Sociedade e

Estado

Table Abbreviations: Lesbian, gay, bisexual, transvestite, transsexual, queer, and intersexual (LGBTQI);

Table 3 Review of Sexuality Issues

\begin{tabular}{|c|c|c|c|c|c|c|}
\hline Article title & Authors & Findings & Method & Year & Journal & Data basis \\
\hline $\begin{array}{l}\text { Descriptive study } \\
\text { of homophobia } \\
\text { and vulnerability } \\
\text { to HIV/Aids of the } \\
\text { transvestites in } \\
\text { the Metropolitan } \\
\text { Region of Recife, } \\
\text { Brazil }\end{array}$ & $\begin{array}{l}\text { de Sousa PJ, Ferreira } \\
\text { LO, De Sa JB }\end{array}$ & $\begin{array}{l}\text { The sample revealed high levels } \\
\text { of homophobia in many different } \\
\text { environments, reports of verbal } \\
\text { aggression }(81.8 \%) \text { and physical } \\
\text { aggression }(68.2 \%) \text {. The elevated } \\
\text { levels of homophobia lead to } \\
\text { suffering and exclusion enhancing } \\
\text { HIV vulnerability among the } \\
\text { Transvestites. }\end{array}$ & $\begin{array}{l}\text { Respondent Driven } \\
\text { Sampling (RDS) }\end{array}$ & 2013 & $\begin{array}{l}\text { Ciência \& } \\
\text { Saúde Coletiva }\end{array}$ & Mendley \\
\hline $\begin{array}{l}\text { Intimate Partner } \\
\text { Violence and } \\
\text { Social Pressure } \\
\text { among Gay Men in } \\
\text { Six Countries }\end{array}$ & $\begin{array}{l}\text { Finneran C, Chard A, } \\
\text { Sineath C, Sullivan P, } \\
\text { Stephenson R, }\end{array}$ & $\begin{array}{l}\text { Experiences of homophobic } \\
\text { discrimination, internalized } \\
\text { homophobia, and heteronormativity } \\
\text { were found to increase odds of } \\
\text { reporting IPV in all countries. }\end{array}$ & Online Survey Study & 2012 & $\begin{array}{l}\text { The Western } \\
\text { Journal of } \\
\text { Emerging } \\
\text { Medicine }\end{array}$ & Mendley \\
\hline
\end{tabular}


Table Contiuned

\begin{tabular}{|c|c|c|c|c|c|c|}
\hline Article title & Authors & Findings & Method & Year & Journal & Data basis \\
\hline $\begin{array}{l}\text { Travestis, an } \\
\text { unexplored } \\
\text { population at risk } \\
\text { of HIV in a large } \\
\text { metropolis of } \\
\text { northeast Brazil: } \\
\text { A respondent- } \\
\text { driven sampling } \\
\text { survey }\end{array}$ & T.A. Martins et al. & $\begin{array}{l}\text { Travestis of the sample are young } \\
(49 \%<24 \text { years), poorly educated } \\
(55 \% \text { just elementary school), } \\
\text { low social class }(62 \% \text { Class C-E), } \\
\text { reside with families }(49 \%) \text { or } \\
\text { friends/ madam }(22 \%) \text {, are victims } \\
\text { of homophobia }(91 \%) \text { and violence } \\
(61 \%) \text {, have high prevalence of HIV } \\
(12 \%) \text {. }\end{array}$ & $\begin{array}{l}\text { Respondent-Driven } \\
\text { Sampling }\end{array}$ & 2013 & $\begin{array}{l}\text { AIDS Care: } \\
\text { Psychological } \\
\text { and Socio- } \\
\text { medical } \\
\text { Aspects of } \\
\text { AIDS/HIV }\end{array}$ & PubMed \\
\hline $\begin{array}{l}\text { Homophobia } \\
\text { or sexism? A } \\
\text { systematic review } \\
\text { of prejudice } \\
\text { against non } \\
\text { heterosexual } \\
\text { orientation in } \\
\text { Brazil }\end{array}$ & Costa et al. & $\begin{array}{l}\text { The reviewed studies indicate that } \\
\text { prejudice against non heterosexual } \\
\text { orientations is an evident and } \\
\text { widespread phenomenon that is } \\
\text { prevalent in various populations and } \\
\text { contexts in Brazil. This phenomenon } \\
\text { is not homogenous and particular } \\
\text { attention is necessary to the } \\
\text { inequality of gender relations. }\end{array}$ & Systematic Review & 13 & $\begin{array}{l}\text { International } \\
\text { Journal of } \\
\text { Psychology }\end{array}$ & PubMed \\
\hline $\begin{array}{l}\text { Religion and the } \\
\text { Rainbow Struggle: } \\
\text { Does Religion } \\
\text { Factor into } \\
\text { Attitudes Toward } \\
\text { Homosexuality } \\
\text { and Same-Sex } \\
\text { Civil Unions in } \\
\text { Brazil? }\end{array}$ & $\begin{array}{l}\text { Ogland, Curtis P, } \\
\text { Verona, Ana Paula }\end{array}$ & $\begin{array}{l}\text { The most restrictive views toward } \\
\text { homosexuality and the strongest } \\
\text { opposition to same-sex civil unions } \\
\text { are most prevalent among devoted } \\
\text { followers of historical Protestant, } \\
\text { Pentecostal, and Catholic faith } \\
\text { traditions, whereas adherents of } \\
\text { Afro-Brazilian and spiritist religions, } \\
\text { as well as those with no religious } \\
\text { commitment, are inclined to assume } \\
\text { a more tolerant moral posture } \\
\text { toward such issues. }\end{array}$ & $\begin{array}{l}\text { Data Analysis of } \\
\text { Brazilian Social } \\
\text { Research Survey } \\
\text { BSRS }\end{array}$ & 2014 & $\begin{array}{l}\text { Journal of } \\
\text { homosexuality }\end{array}$ & EBSCO \\
\hline $\begin{array}{l}\text { Murder of } \\
\text { transvestites } \\
\text { and "pais de } \\
\text { santo" in Brazil: } \\
\text { homophobia, } \\
\text { transphobia } \\
\text { and religious } \\
\text { intolerance. }\end{array}$ & Fernandes, F. B.M & $\begin{array}{l}\text { This study points out that poor, and } \\
\text { black LGBTQI Brazilians linked to } \\
\text { African-Brazilian religions are more } \\
\text { vulnerable to lethal homophobia. }\end{array}$ & Literature Review & 2013 & $\begin{array}{l}\text { Saúde em } \\
\text { Debate }\end{array}$ & SCIELO \\
\hline $\begin{array}{l}\text { Psychosocial } \\
\text { aspects of intra- } \\
\text { family homophobia } \\
\text { and health of } \\
\text { lesbian and gay } \\
\text { youth }\end{array}$ & $\begin{array}{l}\text { J.Perucchi, } \\
\text { B.C.Brandão \& } \\
\text { H.I.S.Vieira }\end{array}$ & $\begin{array}{l}\text { The prejudice articulated in the } \\
\text { family context causes the rupture } \\
\text { of the bond, temporarily or } \\
\text { permanently, among lesbian and gay } \\
\text { youth and their families, which often } \\
\text { leads them to be expelled from } \\
\text { their parents' house in complex and } \\
\text { painful circumstances. }\end{array}$ & $\begin{array}{l}\text { Semi-structured } \\
\text { Interview and } \\
\text { participative } \\
\text { observation }\end{array}$ & 2014 & $\begin{array}{l}\text { Estudos de } \\
\text { Psicologia }\end{array}$ & SCIELO \\
\hline
\end{tabular}

Table Abbreviations: Intimate partner violence (IPV) 


\section{Results and discussion}

\section{Review of education}

In their study, MM Alexander et al. ${ }^{8}$ investigated the relationships of homophobic victimization, teacher support, and school commitment among students from public schools in the state of Paraná, using data from Brazil Preventing School Harassment Survey. ${ }^{8}$ The findings support that homophobic victimization has a negative impact on school commitment, an impact that is stronger when compared to other types of victimization. Similarly, data from the study of Asinelli-Luz \& Cunha ${ }^{9}$ support the negative impact of homophobia on school commitment when high school students who underwent homophobic victimization rated their education lower than students who did not experience that. ${ }^{9}$ In addition, Borges et al. ${ }^{10}$ pointed out that the constant homophobic violence many times lead students to quit school. This situation is also stated by Nardi (2011) among transvestite, transgender, and transsexual people (TTT) who, according to the author, have a hard time at school and only few of them finish the first cycle of school. ${ }^{5,10}$

Data from the study of MM Alexander et al. ${ }^{8}$ also demonstrated that students who experience homophobic victimization are more likely to be target of other kinds of prejudice, and that supportive teachers have a positive effect on school commitment, a greater effect when compared to other types of victimization. ${ }^{8}$ Likewise, Altmann ${ }^{11}$ recognizes the need of supportive teachers and highlights the importance of including sexual diversity and gender in the curriculum of bachelors in education. ${ }^{11}$ This need is further emphasized when Borges et. al. (2011) claim that many times teachers consider homophobic events as common jokes and just give more attention when physical assault happens. ${ }^{10}$

Asinelli-Luz \& Cunha $^{9}$ analysed data of 6,414,302 students from the socioeconomic questionnaire of the National Examination of High School in Brazil (ENEM) between 2004 and 2008. Not surprisingly, the authors found out that the homophobic prejudice is significantly higher among male than female students, the amount of male students who would not like to have homosexual mates was over 3 fold higher than female. ${ }^{9}$ Along with that Nardi highlights the work of Louro in 'Heteronormativity and Homophobia', which pointed out that in Brazilian culture the heteronormativity is more intense or visible among men than women. ${ }^{5}$ In addition, the study of Asinelli-Luz \& Cunha ${ }^{9}$ reported that $4 \%$ of the students had suffered homophobic discrimination while $63.6 \%$ of students had witnessed that in the year of 2008. ${ }^{9}$ On the other hand, the work of Teixeira et al. ${ }^{12}$ which has analysed data of 2,282 high school students from 3 cities of São Paulo, reported that $54.5 \%$ of bisexual students and approximately $80 \%$ of gay and lesbian students had experienced some type of embarrassment or aggression due to their sexuality. ${ }^{12}$

The work of Teixeira et al. ${ }^{12}$ revealed interesting facts, for instance, many of the self-declared bisexual students of the sample did not accept their attraction for people of same biological sex, they reported fear of social exclusion and a desire to change their sexual orientation if it was possible. Students who considered themselves as heterosexual but felt attraction for same biological sex reported that they did not tell anybody about it because of fear of exclusion and intolerance from friends and family. On the other hand, homosexual students of the sample reported that they did not want to change their sexual orientation even though they had suffered embarrassment and aggression due to their sexuality. ${ }^{12}$

The heteronormative character of Brazilian school is emphasized by most of the authors, this institution that could be a source of social change regarding respect to LGTBQI youth is actually one of the main producers of prejudice. ${ }^{5,8,10,11}$ While school keep the emphasis on biological view of sex and does not approach sexual and gender diversity, little of the current scenario will change. ${ }^{10,11}$ Changes on the curriculum of education bachelors or teaching training regarding sexual and gender diversity are extremely necessary as well as more intervention from the government through public policies that could reduce the homophobic violence in school environment. ${ }^{9,11}$ Some of the authors address cultural and religious barriers to include sexual and gender diversity among the themes discussed in school, for instance, there is a cultural belief that discussing sexual diversity at school would incentivize homosexuality among students. Another issue is the pressure from religious groups in the congress to keep the government from implementing policies that address sexual diversity at school..$^{10,11}$ Although school seems to be a key to change the scenario of homophobic violence not only within it but also throughout the society, much needs to be done to overcome the cultural and religious barriers to include sexual and gender diversity in school content to reduce the occurrence of homophobic violence in school.

\section{Review of legislation and policies}

The fight for promotion of LGBTQI citizenship and human rights in Brazil is relatively recent, as Carrara ${ }^{4}$ pointed out the 1988 Brazilian Constitution provided legal basis to create and implement programs to promote equality among heterosexual and LGBTQI people. ${ }^{4}$ Although this Constitution opened space to discussion of sexual rights, it has not addressed prejudice due to sexual orientation and gender identity among the kinds of prejudice to be combated by the government. The work of Carrara emphasizes what the author calls "legislative inertia" since there is a lack of action from the legislative branch to create roles addressing LGBTQI rights. The work of Mello, Brito \& Maroja $^{13}$ confirms this legislative inertia, the authors claimed the importance of the public policies from the executive power since there is a lack of action from the legislative and the judiciary power has a limited access. ${ }^{13}$

Most of the authors reported several barriers to the functioning of programs such as Brazil without Homophobia, School without Homophobia, National Plan for the Promotion of LGBT Citizenship and Human Rights and National Program of Human Rights 3, which tried to address rights to Brazilian LGBTQI population. Although the executive power had created programs aiming to promote rights to the LGBTQI population, these programs have been facing lack of financial support, lack of collaboration among the different spheres of the government, and lack of work force to implement these programs. ${ }^{4,13,14}$ In addition, policies such as School without Homophobia, which tried to distribute anti-homophobia kits to public high schools, suffered pressure from the religious front of the parliament resulting in cancelation of the program..$^{4,13,15}$

Even though there are many different barriers to advances regarding LGBTQI rights there is an agreement among the authors that the religious front of Brazilian parliament is one of the main barriers to current advances. ${ }^{14-16}$ For instance, Mello, Brito \& Maroja ${ }^{13}$ claimed that a great number of law projects have never been discussed or voted in the parliament due to the pressure from religious front and civil society. Aldeman \& Corrêa de Azevedo ${ }^{16}$ pointed out the example of the bill 1154 of 1995, which aimed to legalize the Registered Civil Partnership between same-sex couples, an effort that was kept out of the voting floor of the parliament. ${ }^{16}$ conversely, there is an increase in the number of law projects that are clearly opposed to LGBTQI rights. $^{13}$ 
In this scenario of legislative inertia, the Brazilian Judiciary power is one of the main responsible for the achievement of LGBTQI rights For instance, in 2011 the Brazilian Supreme Federal Court (STF) recognized the equality of same-sex and opposite-sex civil unions extending the rights of heterosexual unions to same-sex unions. Afterwards, the Superior Court of Justice, yet in 2011, based on STF decision recognized the right of same-sex couple in stable union to get married..$^{15-17}$ Therefore, the judiciary power has addressed most of the rights achieved until now, but the problem rises at the limitations of the Judiciary power as it cannot legislate nor build public policies that would combat homophobic violence. Moreover, Freire \& Cardinali ${ }^{15}$ emphasized the need for legislative action, the authors claimed that the current strategies to fight homophobia are failing since there is an increase in reports of homophobic violence what highlights the need for discussing and voting law projects targeting criminalization of homophobia. ${ }^{15}$

The current picture of Brazilian politic arena depicts a reality in which there are some policies from executive power aiming to promote LGTQI citizenship and combat homophobia but at the same time, these programs have little impact since they face several barriers such as lack of financial support and pressure from religious groups in the parliament and in the society. In addition, the rules that emerge in the parliament such as the proposal to criminalize homophobia face a huge disapproval from religious front as well as from great part of Brazilian society. Therefore, the only effective achievements came from Judiciary power but have little to do with fighting homophobia, which demonstrates the importance of more effective actions from the executive and legislative power.

\section{Review of sexuality issues}

A study of Sousa PJ et al. ${ }^{18}$ with 110 transvestites of metropolitan area of Recife investigated the vulnerability of this population to HIV/AIDS, data from the study showed that $81.8 \%$ of the sample had suffered some type of verbal aggression, and $68.2 \%$ physical aggression. ${ }^{18}$ In a similar study, TA Martins et al. ${ }^{19}$ looked at socialdemographic and risk behaviours for HIV and other STDs among 304 transvestites of Fortaleza, this study reported that $61 \%$ of the subjects were target of violence and 91\% target of homophobia. ${ }^{19}$ Data from both studies reveal a situation where violence became a common place for transvestite population, especially in Northeast of Brazil, which is known for its heterosexist culture. Data from the studies confirms the vulnerability of transvestite population due to stigma social isolation, poverty and commercial sex. ${ }^{19}$ The studies highlight what was previously discussed in the section of education that TTT students face high rates of homophobia at school; ${ }^{5}$ the study of Sousa PJ et al..$^{18}$ reported that $33.2 \%$ of transvestites of the sample quitted school due to their sexual orientation or gender identity. ${ }^{18}$

Sousa PJ et al. ${ }^{18}$ also confirm family and neighbourhood environment as places where violence occurs when they report that $47.3 \%$ of transvestites experienced prejudice in these environments. ${ }^{18}$ $\mathrm{J}$ Perucchi et al. ${ }^{20}$ emphasize that family usually is not a network of support since it remains as source of violence to LGBTQI people. ${ }^{20}$ Conversely, health care providers and police workers that could be helpful networks are many times responsible for homophobic violence against transvestites. ${ }^{18,19,21}$ According to the authors, this scenario of violence, social exclusion, and poor networks of support enhance vulnerability to HIV/AIDS to the transvestite population. ${ }^{18,19}$

The study of Finneran et al. ${ }^{22}$ investigated intimate partner violence (IPV) among men who have sex with men (MSM) from 6 countries including Brazil, the findings strongly indicate that the heteronormative pressure from society acts as a risk factor for reporting of IPV among MSM. ${ }^{22}$ None of the other studies in this integrative review investigated IPV among LGBTQI population, which indicates a need for more investigation regarding this theme. Although we did not find a similar study in this review, it is possible to correlate the findings of the cited study with the words of Costa et al. ${ }^{2}$ that point in their study that the sexist character of Brazilian society leads to violence and prejudice against LGBTQI population. ${ }^{2}$ Moreover, according to Finneran and colleagues, the heteronormative pressure may enhance IPV when MSM feel that they must hide their relationships or when it interacts with internalized homophobia.

The work of Costa and colleagues, which reviewed the literature regarding prejudice against LGBTQI people in Brazil, addresses some of the main gaps of the current research. ${ }^{2}$ For instance, the authors reported that the findings of the current research could not be generalized because most of the studies focus on south and southeast of Brazil and, therefore, there is a need for more regionalized studies and further nationwide studies. The authors also emphasized the need for studies taking account of social markers such as social class, race, age, education and religion, which J Perucchi et al..$^{20}$ highlight when the authors state that homophobia affect differently its targets depending on their social markers..$^{20}$ The work of these authors aimed to investigate the effects of homophobia into family relationships of gay and lesbian youth. Although this study had a limited sample, only 10 subjects, it highlighted some important aspects such as "coming out of the closet" as a trigger of familiar conflict, this conflict as predictor of family rupture, and the homophobic violence occurring in the dayto-day activities. The only study that measured homophobic violence in the family group was the study of Sousa PJ et al. ${ }^{18}$ which points out the need for more studies measuring intra-familiar homophobia. ${ }^{18}$

C Ogland \& AP Verona ${ }^{6}$ analysed data of 2,364 subjects of Brazilian Social Research Survey (BSRS) to exam the relationship among religion, the view of homosexuality, and same-sex civil unions. The authors found out that devoted followers of Catholic and Pentecostal faith are more likely to disapprove homosexuality when compared to their nominal counterparts. Pentecostal and historical Protestant followers have a more restrictive view when compared to nominal Catholics. In addition, followers of Spiritist traditions and religious nones are significantly less likely to disapprove homosexuality when compared to Catholics, historical Protestants and Pentecostals. ${ }^{6}$ Alternatively, Martins ${ }^{21}$ investigated the vulnerability to lethal violence among transvestites and homosexual men linked to African-Brazilian religions, for instance, the author emphasizes the Pentecostal discourse which triggers intolerant view toward AfricanBrazilian religions justified by the proselytism (fight to eliminate the devil). ${ }^{21}$ Therefore, this group of the LGBT population is especially vulnerable due to their sexual orientation and their faith. The authors agree that the action of religious groups holding restrictive view toward homosexuality will continue to represent forces against the LGBT rights, especially with rising action of religious leaders in the political sphere.

\section{Conclusion}

The research regarding violence against Brazilian LGBTQI population is a recent trend. Therefore, there is a lack of studies focused, for example: in the social markers linked to this violence; studies quantifying the violence and describing its characteristics; studies looking at motivations of violence or linking it to cultural, social or religious practices; regionalized studies looking at specificities of Brazilian regions and further nationwide studies; and, studies 
measuring the effectiveness of governmental programs and policies that aim to enhance LGBQI citizenship and combat homophobia. Although this review may be limited due to the data basis used and the chosen key-words, it is possible to have a good picture of the current research that points out the struggle of LGBTQI population in Brazil that faces violence in school, family, and in the whole society. In addition, this population still faces the lack of resources of help/support. Finally, the research regarding violence against this vulnerable population is extremely important as it can guide future actions to fight homophobia and promote LGBTQI citizenship.

\section{Acknowledgements}

None.

\section{Conflict of interest}

The authors declare that there is no conflict or financial interest.

\section{References}

1. Balzer C. Every 3 rd day the murder of a trans person is reported Preliminary results of a new Trans Murder Monitoring Project show more than 200 reported cases of murdered trans people from January 2008 to June 2009. Liminalis. 2009;147-159.

2. Costa A, Peroni R, Bandeira D, et al. Homophobia or sexism? A systematic review of prejudice against nonheterosexual orientation in Brazil. International Journal of Psychology. 2012; 48(5):900-909.

3. Do Amaral Madureira A.The psychological basis of homophobia: Cultura construction of a barrier. Integrative Psychological and Behavioral Science.2007;41(3-4):225-247.

4. Carrara S. Discrimination, policies, and sexual rights in Brazil. Cadernos de Saúde Pública. 2012;28(1):184-189.

5. Nardi H. Theoretical Approaches and Policies in Sexual Diversity and Educational in Brazil: A Critical Review. Journal of LGBT Youth 2011;8(2):201-209.

6. Ogland C, Verona A. Religion and the Rainbow Struggle: Does Religion Factor into Attitudes Toward Homosexuality and Same-Sex Civil Unions in Brazil?. J Homosex. 2014;61(9):37-41.

7. Mendes K, Silveira R, Galvão C. Intregative Literature Review: a research method to incorporate evidence in health care and nursing. Texto Contexto Enfermagem. 2008;17(4):758-764

8. Alexander M, Santo J, Da Cunha J, et al. Effects of Homophobic versus Nonhomophobic Victimization on School Commitment and the Moderating Effect of Teacher Attitudes in Brazilian Public Schools. Journal of LGBT Youth. 2011;8(4):289-308.
9. Asinelli-Luz A, Cunha J. Percepções sobre a discriminação homofóbica entre concluintes do ensino médio no Brasil entre 2004 e 2008. Educar Em Revista. 2011;(39):87-102.

10. Borges Z, Passamani G, Ohlweiler M, et al. Percepção de professoras de ensino médio e fundamental sobre a homofobia na escola em Santa Maria (Rio Grande do Sul/Brasil). Educar Em Revista. 2011;(39):21-38.

11. Altmann H. Diversidade sexual e educação: desafios para a formação docente. Sexualidad, Salud Y Sociedad. 2013;(13):69-82.

12. Teixeira F, Marretto C, Mendes A. Homophobia and Sexuality in Adolescents: Sexual Trajectories, Risks And Vulnerabilities. Psicologia: Ciência E Profissão. 2012;32(1):16-33.

13. Mello L, Brito W, Maroja D. Public Measures for the LGBT Population in Brazil: Notes About Reaches and Possibilities. Cadernos Pagu. 2012;(39):403-429.

14. Mello L, Avelar R, Maroja D. Where are the Public Politics for the Brazilian LGBT Population. Sociedade E Estado. 2012;27(2):289-312.

15. Freire L, Cardinali D. O ódio atrás das grades: da construção social da discriminação por orientação sexual à criminalização da homofobia. Sexualidad, Salud Y Sociedad (Rio de Janeiro). 2012;(12):37-63.

16. Adelman M, Corrêa de Azevedo M. Families, Gender Relations and Social Change in Brazil: Practices, Discourse, Policy. Journal of Child and Family Studies. 2012;21(1):65-74.

17. Narrain A. Brazil, India, South Africa: transformative constitutions and their role in LGBT struggles. International Journal on Human Rights. 2014;8(20):150-166.

18. De Sousa P, Ferreira L, De Sa J. Descriptive study of homophobia and vulnerability to HIV/Aids of the transvestites in the Metropolitan Region of Recife, Brazil. Ciencia Saude Coletiva. 2013;18(8):2239-2251.

19. Martins T, Kerr L, Macena R, et al. Travestis, an unexplored population at risk of HIV in a large metropolis of northeast Brazil: A respondent- driven sampling survey. AIDS Care: Psychological and Socio-Medical Aspects of AIDS/HIV. 2013;25(5):606-6012.

20. Perucchi J, Brandão B, Vieira H. Aspectos psicossociais da homofobia intrafamiliar e saúde de jovens lésbicas e gays. Estudos de Psicologia. 2014;19(1):67-76.

21. Martins FB. Assassinatos de travestis e " pais de santo" no Brasil: homofobia, transfobia e intolerância religiosa. Saúde Em Debate. 2013;37(98):485-492.

22. Finneran C, Chard A, Sineath C, et al. Intimate Partner Violence and Social Pressure among Gay Men in Six Countries. West J Emerg Med. 2012;13(3): 260-271. 